\title{
Original Can pre-insertion uterine artery Doppler indices Article predict intrauterine contraceptive device-related heavy menstrual bleeding?
}

\section{Marwa A. Ibrahim ${ }^{1}$, Naglaa H. Mohammed ${ }^{2}$ and Hala W. Abdel Halim².}

${ }^{1}$ Obstetrics and Gynecology Department, El-Shiekh Zayd Al-Nahyan Hospital, Cairo, Egypt.

${ }^{2}$ Obstetrics and Gynecology Department, Faculty of Medicine for Girls, Cairo, Al-Azhar University, Egypt.

\section{ABSTRACT}

Background: The intrauterine contraceptive device (IUCD) is a frequently used method of contraception all-over the world. The most common side effect of IUCD is menorrhagia which is accountable for increased removal rate in the first year of its use.

Objective: To test the hypothesis that initial uterine artery pulsatility index (PI) and resistance index (RI) before insertion of Tcu 380A IUCD could predict IUCD-related heavy menstrual bleeding or not.

Methodology: A cohort study was performed on 300 women who demanded copper IUCD insertion as a method of contraception. Full history, detailed examination and investigations were done. Hemoglobin (Hb) concentration and PI and RI of uterine artery were measured using voluson B6 equipment before IUCD insertion and 3 and 6 months after insertion.

Results: 162 participants who suffered from heavy menstrual bleeding (group II) had significantly lower uterine artery PI and RI than 138 participants who did not suffer from heavy menstrual bleeding (group I) before IUCD insertion and 3 and 6 months after insertion (p-value $<0.001)$. Uterine artery Doppler indices showed no statistically significant changes after insertion of IUCD in each separate group (p-value >0.05). 64 participants in group II with severe heavy menstrual bleeding required removal of the IUCD at the 3 months follow up visit. A cut-off levels for Doppler indices of uterine artery were $\mathrm{PI} \leq 1.52$ and $\mathrm{RI} \leq 0.66$.

Conclusion: PI and RI of uterine artery are lower in patients with IUCD-induced heavy menstrual bleeding before IUCD insertion. Initial measurement of Doppler indices of uterine artery could predict IUCD-related heavy bleeding.

JRAM 2021; 2 (2):184-193

Keywords: Copper intrauterine contraceptive device; heavy menstrual bleeding; uterine artery doppler indices.

Submission Date: 20 December 2020

Acceptance Date: 19 February 2021

Corresponding author: Marwa Alaa Eldin Ibrahim, Obstetrics and gynecology department, El-Shiekh Zayd Al-Nahyan Hospital, Cairo, Egypt. Tel: 01030353009. E-mail: marwa.unique@gmail.com

Please cite this article as: Ibrahim MA, Mohammed $\mathrm{NH}^{\prime}$ and Abdel Halim HW. Can pre-insertion uterine artery Doppler indices predict intrauterine contraceptive device-related heavy menstrual bleeding? JRAM 2021; 2 (2):184-193. DOI: 10.21608/jram.2021.54112.1105

\section{INTRODUCTION}

The Intrauterine Contraceptive Devices (IUCDs) are very popular as a contraceptive method in family planning used worldwide. The mode of action is based on the spermicidal effect of the released copper ions. In addition, the device creates a hostile uterine environment as a result of an inflammatory process ${ }^{[1]}$. The most frequent adverse effects resulted from the use of IUCD are heavy menstrual bleeding and dysmenorrhea ${ }^{[2]}$. Normal menstrual duration varies from 3 to 6 days and includes blood loss up to $30 \mathrm{ml}$. Menorrhagia is demarcated as menstrual duration lasting $>7$ days and/or involving blood loss $>80 \mathrm{ml}^{[3]}$. There are multiple possible processes that clarify the cause of the excessive bleeding in women using IUCD including increased secretion of prostaglandins in the endometrium which cause a rise in vascularity, vascular permeability, and prevent platelet activity and consequently increased menstrual bleeding ${ }^{[4]}$.

Another mechanism is that the IUCD increases the fibrinolysis as a result of the injury in the capillary plexus ${ }^{[5]}$. The blood loss in copper IUCD users increased nearly $30-50 \%$ of the normal with about 10 $20 \%$ of users demand to remove the IUCD during the first year of insertion ${ }^{[6]}$. There is also an increase in the microvascularization of the sub-endometrium in those women who complained of IUCD-induced heavy bleeding ${ }^{[7]}$. Based on these findings, PI and RI of the uterine artery were extensively investigated with contradicting results in order to recognize the vascular 
changes of the uterus in patients with IUCD induced bleeding ${ }^{[8]}$.

\section{PATIENTS AND METHODS}

This is a prospective cohort study that was performed on 300 patients who were seeking IUCD insertion in obstetrics and gynaecology department at AL Zahraa University Hospital and El-Shiekh Zayd Al-Nahyan Hospital in the period between November 2019 and August 2020. The study was approved by the institutional review board of faculty of medicine for girls, Cairo, Al-Azhar university, Egypt. An informed consent was taken from all participants before starting the study.

Inclusion criteria: Age between 20-40 years old; Multiparous women; Regular menstrual cycles with average amount of bleeding.

Exclusion criteria: Lactating women; hormonal treatment in the last 3 months; presence of uterine, cervical or adnexal pathology e.g. myomas, polyps and endometriosis; presence of vaginal or pelvic infection; medical disorders e.g. hypertension and coagulopathy; any contraindication to IUCD insertion and women using anti-coagulant medications.

All participants were subjected to a detailed history taking including menstrual history, obstetric history, medical history and past history of previous operations. They were also subjected to full general and local examination, with laboratory and ultrasound investigations.

\section{On the day of IUCD insertion:}

Instructions were given to the participants to stop nonsteroidal anti-inflammatory drugs intake 24 hours prior to the examination. Participants were asked to empty the urinary bladders to avoid modification of artery impedance. Ultrasound examination was done from 9:00 am to $12: 00 \mathrm{pm}$ to avoid diurnal variations of the factors affecting uterine artery Doppler indices. IUCD insertion was done on day 3-5 of the cycle. A 2D transvaginal ultrasound was done using Voluson B6 equipment with 6-9 $\mathrm{MHz}$ transducer (the same equipment at both hospitals) to measure the size of the uterus and to exclude any abnormality in the uterus or adnexae with pulsed wave color Doppler study on the uterine artery main branch on either both side at the internal cervical os level on a longitudinal plane measuring PI and RI. Then, under complete aseptic conditions, a Tcu 380A IUCD was inserted, and transvaginal ultrasound was repeated after insertion to make sure that the IUCD is in the correct place.

A menstrual calendar was given to the participants to record events of the menstrual cycle as recommended by WHO (1981) as follows: bleeding period, bleedingfree period, menstrual segment (includes the bleeding period and the bleeding free period), inter-menstrual spotting and heavy bleeding ${ }^{[9]}$.

Participants were also asked to record the following: How many pads used per day? Were the pads soaked or not? Was there a passage of blood clots during the menstruation? Were there any symptoms like drowsiness, easy fatigue, palpitation, fainting or blurring of vision?

Follow up visits were done at 3 and 6 months after insertion at day 3-5 of the menstrual cycle to do the following: measure the haemoglobin concentration; vaginal ultrasound to make sure that the IUCD is in the correct place; colour pulsed Doppler to measure uterine artery Doppler indices; checking the menstrual history and the menstrual calendar of the previous 3 months. Heavy menstrual bleeding was diagnosed if $>$ 8 soaked pads or 16 non-soaked pads were used throughout the menstrual duration and/or menstrual duration $>7$ days, with the passage of blood clots and the presence of one or more of the associated symptoms (drowsiness, easy fatigue, palpitation, fainting and blurring of vision). Participants were instructed if heavy bleeding occurred, they should have complete rest during menstruation and increase intake of iron and vitamin B12 rich diet. However, if the bleeding continued, they should seek medical care immediately. Removal of IUCD should be considered if the bleeding was as twice as heavy or as twice if usual, the bleeding changes were very bothersome, presence of severe anaemia or the bleeding changes lasted $>6$ months ${ }^{[10]}$.

The participants were divided during the first follow up visit after 3 months based on the occurrence of IUCD related heavy menstrual bleeding into two groups: (group I: Non-heavy bleeding): included 138 participants who didn't suffer from heavy menstrual bleeding and (group II: Heavy bleeding): included 162 participants suffered from with heavy menstrual bleeding .

\section{Statistical analysis}

The sample size was calculated with power 0.8 , effect size 0.25 and significance level 0.05 , the result of sample size calculation was 126 participants. The collected data were analysed using the statistical package for social sciences, version 20.0 (SPSS Inc., Chicago, Illinois, USA). Quantitative data were expressed as mean \pm standard deviation (SD). Qualitative data were expressed as frequency and percentage. Independent-samples t-test of significance was used when comparing between two means, Mann Whitney z-test: for two-group comparisons in nonparametric data, the repeated measures ANOVA tests for whether there are any differences between related means, Pearson's correlation coefficient (r) test was used to assess the degree of association between two sets of variables and Chi-square $\left(\mathrm{x}^{2}\right)$ test of significance was used to compare proportions between qualitative parameters. P-value $<0.05$ was considered significant. Receiver operating characteristic (ROC) curve analysis was used to assess the predictive value of PI and RI of uterine artery at the highest levels of sensitivity and specificity. 


\section{RESULTS}

In this study 300 women were included, $46.0 \%$ of them did not suffer from heavy menstrual bleeding (Group I) and $(54 \%)$ suffered from heavy menstrual bleeding (Group II)

Participants in the heavy bleeding group (group II) were subdivided according to the severity of the heavy bleeding into two categories: Group II/a: 98 participants $(60.5 \%)$ with mild to moderate heavy bleeding that did not interfere with daily activity and completed the 6 months follow up visits and group II/b: 64 participants $(39.5 \%)$ with severe heavy bleeding that required removal of IUCD before completing the 6 months follow up visits. The results of this study showed no significant difference between the two groups according to the baseline characteristics (as age, parity, BMI) and the cycle length ( $\mathrm{p}$-value $>0.05$ ) (table 1).

Table (1): Comparison between group I and group II as regards baseline characteristics and cycle length before IUCD insertion and 3 and 6 months after insertion

\begin{tabular}{|c|c|c|c|c|c|}
\hline Baseline characteristics & $\begin{array}{c}\text { Group I: } \\
\text { Non-heavy } \\
\text { bleeding }(n=138)\end{array}$ & \multicolumn{2}{|c|}{$\begin{array}{l}\text { Group II: } \\
\text { Heavy bleeding }(\mathrm{n}=162)\end{array}$} & Test & p-value \\
\hline $\begin{array}{l}\text { Age (years) } \\
\text { Mean } \pm \text { SD } \\
\text { Range }\end{array}$ & $\begin{array}{c}31.2 \pm 4.4 \\
21-40\end{array}$ & \multicolumn{2}{|c|}{$\begin{array}{c}31.2 \pm 4.7 \\
20-39\end{array}$} & $\mathrm{t}=-0.32$ & 0.75 \\
\hline $\begin{array}{l}\text { Parity } \\
\text { Median (IQR) } \\
\text { Range }\end{array}$ & $\begin{array}{c}2(1) \\
1-4\end{array}$ & \multicolumn{2}{|c|}{$\begin{array}{c}2(2) \\
1-4\end{array}$} & $\mathrm{z}=-0.01$ & 0.99 \\
\hline $\begin{array}{l}\text { BMI }\left[w t /(h t)^{2}\right] \\
\text { Mean } \pm \text { SD } \\
\text { Range }\end{array}$ & $\begin{array}{c}27.0 \pm 3.5 \\
18.98-33.02\end{array}$ & \multicolumn{2}{|c|}{$\begin{array}{c}27.1 \pm 3.5 \\
19.76-33.61\end{array}$} & $\mathrm{t}=-0.77$ & 0.44 \\
\hline Cycle length (days) & $\begin{array}{l}\text { Group I: } \\
(n=138)\end{array}$ & $\begin{array}{c}\text { Group II/a } \\
(n=98)\end{array}$ & $\begin{array}{l}\text { Group II/b } \\
(n=64)\end{array}$ & $\begin{array}{l}\text { Group I vs. } \\
\text { Group II }\end{array}$ & \\
\hline \multicolumn{6}{|l|}{ Before IUCD insertion } \\
\hline $\begin{array}{l}\text { Mean } \pm \text { SD } \\
\text { Range }\end{array}$ & $\begin{array}{c}29.8 \pm 1.4 \\
28-34\end{array}$ & $\begin{array}{c}29.7 \pm 1.6 \\
27-34\end{array}$ & $\begin{array}{c}29.6 \pm 1.6 \\
27-34\end{array}$ & $\mathrm{t}=0.36$ & 0.71 \\
\hline \multicolumn{6}{|l|}{ After 3 months } \\
\hline $\begin{array}{l}\text { Mean } \pm \text { SD } \\
\text { Range }\end{array}$ & $\begin{array}{c}29.8 \pm 1.4 \\
28-33\end{array}$ & $\begin{array}{c}29.7 \pm 1.6 \\
27-34\end{array}$ & $\begin{array}{c}29.7 \pm 1.6 \\
27-34\end{array}$ & $\mathrm{t}=0.17$ & 0.87 \\
\hline \multicolumn{6}{|l|}{ After 6 months } \\
\hline $\begin{array}{l}\text { Mean } \pm \text { SD } \\
\text { Range }\end{array}$ & $\begin{array}{c}29.8 \pm 1.4 \\
28-33\end{array}$ & $\begin{array}{c}29.7 \pm 1.6 \\
27-34\end{array}$ & ---------- & $\mathrm{t}=0.30$ & 0.77 \\
\hline
\end{tabular}

BMI: Body Mass Index, *: p-value <0.05.

The results of this study showed that 73 Participants out of $138(52.9 \%)$ in group I had primary dysmenorrhea however all cases in group II have no dysmenorrhea before IUCD insertion with statistically significant difference. (p-value <0.001) (figure 1).

There was a statistically significant increase in the menstrual duration after IUCD insertion in group II (in both subgroups) in comparison to group I (p-value $<0.001)$. This increase was higher in group II/b ( $p$ value $<0.001$ ). There was also a statistically significant increase in the amount of bleeding as regards the number of sanitary pads after IUCD insertion in group II (in both subgroups) versus group I (p-value <0.001). This increase was higher in group II/b than group II/a (p-value <0.001). Moreover, there was no statistically significant difference between the two groups in basal haemoglobin levels with a decrease in $\mathrm{Hb}$ concentration after IUCD insertion in group II (in both subgroups) when compared to group I, (p-value < $0.001)$. This decrease was more in group II/b than group II/a (p-value <0.001) (table 2).
The results of this study showed that PI and RI of uterine artery were lower in group II (in both subgroups) than group I either before or after insertion of IUCD and this is highly statistically significant (pvalue $<0.001$ ). While subgroups II/a and II/b did not show a significant difference regarding PI and RI of uterine artery either before or after insertion of IUCD (p-value >0.05) (table 2 and figure 2). There was no statistically significant change in uterine artery PI and RI after IUCD insertion in each individual group throughout the follow-up period (3-6 months) (p-value $>0.05$ ) (table 3 and figure 2).

There was a highly statistical significant negative correlation between Doppler indices of uterine artery and menstrual duration and the amount of bleeding 3 and 6 months after IUCD insertion and a highly statistical significant positive correlation between uterine artery Doppler indices and dysmenorrhea, bleeding free interval and $\mathrm{Hb}$ concentration, before insertion and 3 and 6 months after insertion in case of 
dysmenorrhea and 3 and 6 months after insertion in case of bleeding free interval and $\mathrm{Hb}$ concentration ( $\mathrm{p}$ value $<0.001$ ) (table 4).

Cut-off levels for PI and RI of uterine artery were set with PI cut-off level $\leq 1.52$ with sensitivity of $98.6 \%$, specificity of $96.9 \%$ and area under the curve (AUC) of 98.9. RI cut-off level $\leq 0.66$ with sensitivity of $97.8 \%$, specificity of $96.7 \%$ and AUC of 95.9. These cut-off levels were associated with heavy menstrual bleeding (figure 3 and table 5).

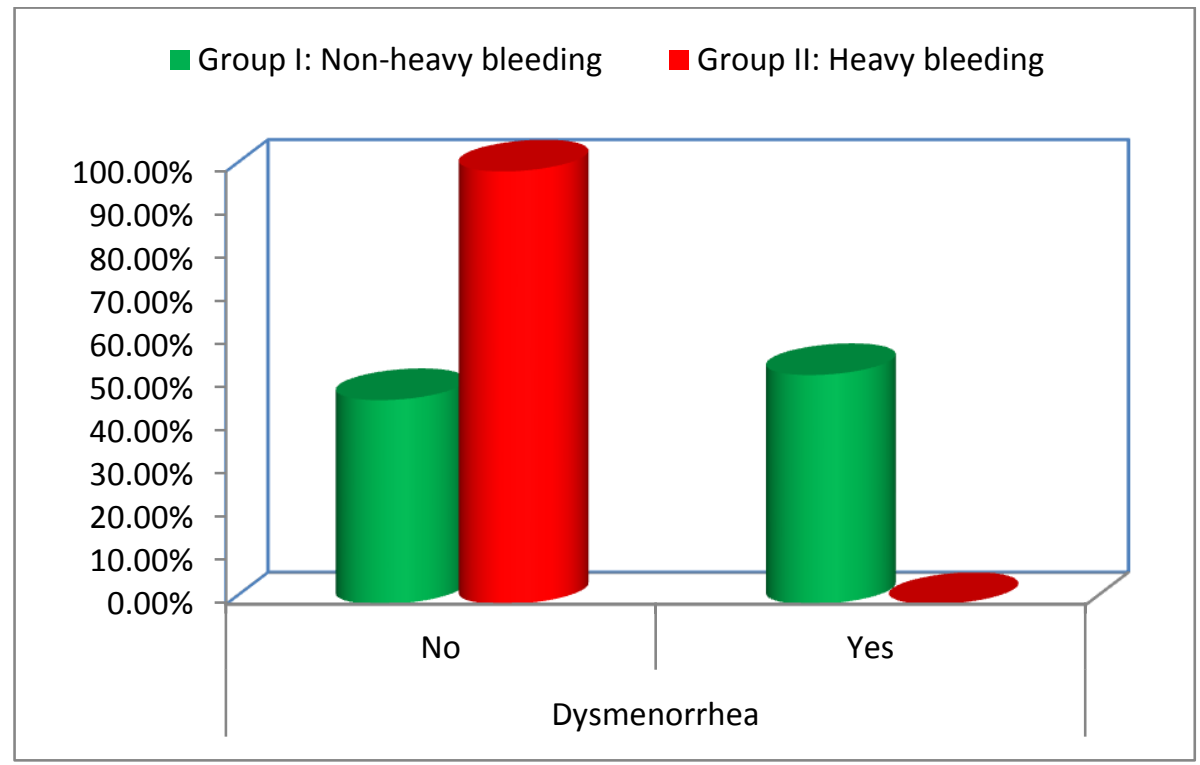

Fig. (1): Bar chart between group I and group II according to history dysmenorrhea before IUCD insertion

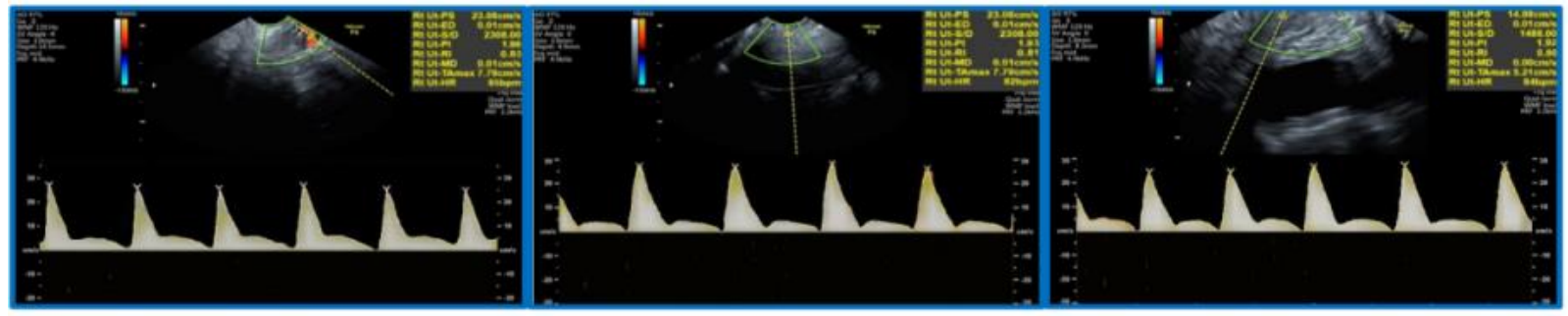

$1 \mathbf{a}$

$1 \mathbf{b}$

1c

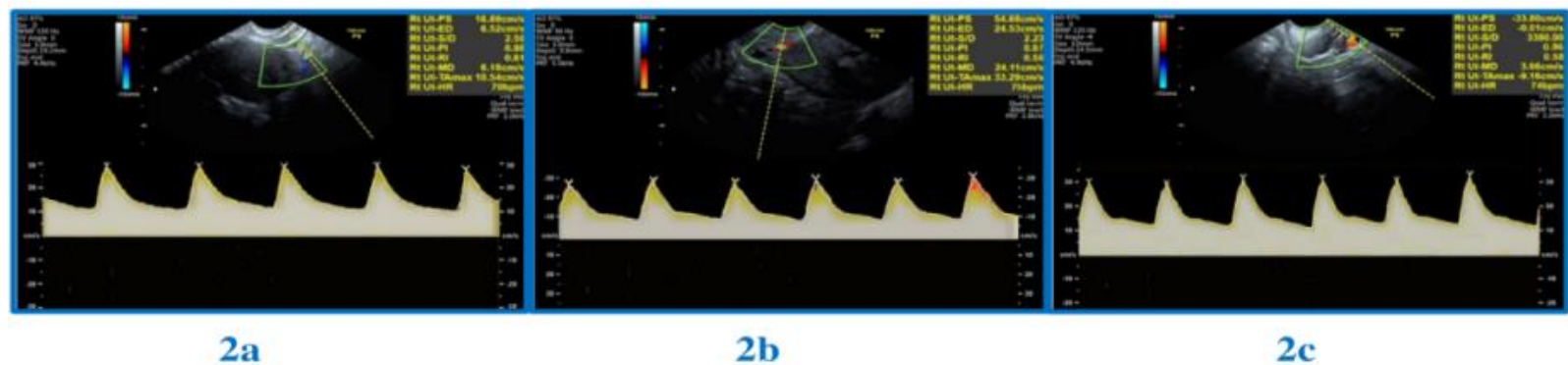

Fig. (2): 1a, 1b and 1c: participant from group I (non-heavy bleeding) before insertion and 3 and 6 months after insertion, respectively. 2a, 2b and 2c: participant from group II/a (mild to moderate heavy bleeding) before insertion and 3 and 6 months after insertion, respectively. 
Table (2): Comparison between group I and group II according to menstrual duration, amount of bleeding, Hb concentration and uterine artery PI and RI

\begin{tabular}{|c|c|c|c|c|c|c|}
\hline \multirow{2}{*}{ Items } & \multirow{2}{*}{$\begin{array}{l}\text { Group I: } \\
\text { Non-heavy } \\
\text { bleeding } \\
(\mathrm{n}=138)\end{array}$} & \multicolumn{2}{|c|}{$\begin{array}{c}\text { Group II: } \\
\text { Heavy bleeding }(\mathrm{n}=162)\end{array}$} & \multirow{2}{*}{$\begin{array}{l}\text { t-test } \\
\text { Group I vs. } \\
\text { Group II }\end{array}$} & \multirow{2}{*}{$\begin{array}{c}\text { p-value } \\
\text { Group I vs. } \\
\text { Group II }\end{array}$} & \multirow{2}{*}{$\begin{array}{c}\text { p-value } \\
\text { Group II/a vs } \\
\text { Group II/b }\end{array}$} \\
\hline & & $\begin{array}{c}\text { Group II/a } \\
\quad(n=98)\end{array}$ & $\begin{array}{c}\text { Group II/b } \\
(n=64)\end{array}$ & & & \\
\hline \multicolumn{7}{|c|}{ Menstrual duration\ days } \\
\hline $\begin{array}{l}\text { Before IUCD Insertion } \\
\text { Mean } \pm \text { SD } \\
\text { Range }\end{array}$ & $\begin{array}{c}6.2 \pm 0.7 \\
5-7\end{array}$ & $\begin{array}{c}6.3 \pm 0.6 \\
5-7\end{array}$ & $\begin{array}{c}6.3 \pm 0.7 \\
5-7\end{array}$ & -1.19 & 0.33 & 0.36 \\
\hline $\begin{array}{l}\text { After } 3 \text { months } \\
\text { Mean } \pm \text { SD } \\
\text { Range }\end{array}$ & $\begin{array}{c}6.5 \pm 0.6 \\
5-8\end{array}$ & $\begin{array}{c}7.3 \pm 0.7 \\
6-9\end{array}$ & $\begin{array}{c}7.7 \pm 0.5 \\
7-9\end{array}$ & -9.33 & $0.001 * *$ & $0.001 * *$ \\
\hline $\begin{array}{l}\text { After } 6 \text { months } \\
\text { Mean } \pm \text { SD } \\
\text { Range }\end{array}$ & $\begin{array}{c}6.5 \pm 0.6 \\
5-8\end{array}$ & $\begin{array}{c}7.3 \pm 0.7 \\
6-9\end{array}$ & ---------- & -9.33 & $<0.001 * *$ & --------- \\
\hline \multicolumn{7}{|c|}{ Amount of bleeding (pads/cycle) } \\
\hline $\begin{array}{l}\text { Before IUCD Insertion } \\
\text { Mean } \pm \text { SD } \\
\text { Range }\end{array}$ & $\begin{array}{c}10.6 \pm 2.5 \\
7-14\end{array}$ & $\begin{array}{c}10.7 \pm 2.6 \\
7-14\end{array}$ & $\begin{array}{c}10.7 \pm 2.5 \\
7-14\end{array}$ & -1.95 & 0.19 & 0.26 \\
\hline $\begin{array}{l}\text { After } 3 \text { months } \\
\text { Mean } \pm S D \\
\text { Range }\end{array}$ & $\begin{array}{l}10.8 \pm 2.4 \\
7-15\end{array}$ & $\begin{array}{c}17.2 \pm 3.6 \\
15-22\end{array}$ & $\begin{array}{c}21.5 \pm 3.6 \\
22-27\end{array}$ & -12.40 & $0.001 *$ & $0.001 *$ \\
\hline $\begin{array}{l}\text { After } 6 \text { months } \\
\text { Mean } \pm \text { SD } \\
\text { Range }\end{array}$ & $\begin{array}{c}10.9 \pm 2.2 \\
7-15\end{array}$ & $\begin{array}{c}17.3 \pm 3.4 \\
15-22\end{array}$ & --------- & -11.77 & $0.001 *$ & --------- \\
\hline \multicolumn{7}{|c|}{ Hb $(\mathrm{gm} / \mathrm{dl})$} \\
\hline \multicolumn{7}{|l|}{ Before IUCD insertion } \\
\hline Mean \pm SD & $12.4 \pm 0.9$ & $12.3 \pm 0.9$ & $12.4 \pm 0.9$ & \multirow{2}{*}{1.17} & \multirow{2}{*}{0.30} & \multirow{2}{*}{0.37} \\
\hline Range & $10.3-14.2$ & $10.1-14.6$ & $10.2-14.5$ & & & \\
\hline \multicolumn{7}{|l|}{ After 3 months } \\
\hline $\begin{array}{l}\text { Mean } \pm \text { SD } \\
\text { Range }\end{array}$ & $\begin{array}{c}12.4 \pm 0.9 \\
10.1-14.3\end{array}$ & $\begin{array}{c}11.6 \pm 1.0 \\
9.1-14\end{array}$ & $\begin{array}{c}11.0 \pm 0.9 \\
9-13.5\end{array}$ & 6.19 & $0.001 *$ & $0.001 *$ \\
\hline \multicolumn{7}{|c|}{ After 6 months } \\
\hline Mean \pm SD & $12.4 \pm 0.9$ & $11.6 \pm 1.0$ & & & & \\
\hline Range & $10-14.1$ & $9-13.7$ & ---------- & 6.50 & $0.001 *$ & ---------- \\
\hline \multicolumn{7}{|c|}{ Uterine artery PI } \\
\hline \multicolumn{7}{|l|}{ Before IUCD insertion } \\
\hline Mean \pm SD & $1.9 \pm 0.2$ & $1.2 \pm 0.2$ & $1.2 \pm 0.1$ & \multirow{2}{*}{32.97} & \multirow{2}{*}{$0.001 *$} & \multirow{2}{*}{0.39} \\
\hline Range & $1.53-2.25$ & $0.9-1.52$ & $0.89-1.51$ & & & \\
\hline \multicolumn{7}{|l|}{ After 3 months } \\
\hline Mean \pm SD & $1.9 \pm 0.2$ & $1.2 \pm 0.2$ & $1.2 \pm 0.1$ & \multirow{2}{*}{33.11} & \multirow{2}{*}{$0.001 *$} & \multirow{2}{*}{0.37} \\
\hline Range & $1.53-2.25$ & $0.89-1.5$ & $0.88-1.49$ & & & \\
\hline After 6 months & & & & & & \\
\hline $\begin{array}{l}\text { Mean } \pm \text { SD } \\
\text { Range }\end{array}$ & $\begin{array}{c}1.9 \pm 0.2 \\
1.53-2.25\end{array}$ & $\begin{array}{l}1.2 \pm 0.2 \\
0.88-1.5\end{array}$ & ---------- & 33.17 & $0.001 *$ & ---------- \\
\hline & & Uterine & ery RI & & & \\
\hline Before IUCD insertion & & & & & & \\
\hline Mean \pm SD & $0.8 \pm 0.06$ & $0.6 \pm 0.05$ & $0.6 \pm 0.03$ & 27.83 & $0.001 *$ & 0.29 \\
\hline Range & $0.67-0.88$ & $0.48-0.66$ & $0.47-0.65$ & 21.03 & 0.001 & 0.29 \\
\hline After 3 months & & & & & & \\
\hline Mean \pm SD & $0.8 \pm 0.06$ & $0.6 \pm 0.04$ & $0.6 \pm 0.03$ & & & \\
\hline Range & $0.67-0.88$ & $0.47-0.65$ & $0.46-0.64$ & 28.37 & $0.001^{*}$ & 0.28 \\
\hline After 6 months & & & & & & \\
\hline Mean \pm SD & $0.8 \pm 0.06$ & $0.6 \pm 0.04$ & ---------- & & & ---------- \\
\hline Range & $0.67-0.87$ & $0.47-0.65$ & & 28.34 & $0.001^{*}$ & \\
\hline
\end{tabular}


Table (3): The extent of the differences in the Doppler indices in both groups throughout the follow-up period

\begin{tabular}{|l|c|c|c|c|c|}
\hline $\begin{array}{c}\text { Group I: } \\
\text { Non-heavy bleeding }(\mathbf{n = 1 3 8})\end{array}$ & Pre & After 3 months & After 6 months & ANOVA & p-value \\
\hline Uterine artery PI & $1.9 \pm 0.2$ & $1.9 \pm 0.2$ & $1.9 \pm 0.2$ & 0.98 & 0.29 \\
\hline Uterine artery RI & $0.8 \pm 0.06$ & $0.8 \pm 0.06$ & $0.8 \pm 0.06$ & 0.96 & 0.31 \\
\hline \multicolumn{1}{|c|}{ Group II: } & & & $\begin{array}{c}\text { Group II/a } \\
(\mathbf{n = 9 8})\end{array}$ & & \\
\hline \multicolumn{1}{|c|}{ Heavy bleeding $(\mathbf{n = 1 6 2 )}$} & & & $1.2 \pm 0.2$ & 1.13 & 0.20 \\
\hline Uterine artery PI & $1.2 \pm 0.2$ & $1.2 \pm 0.2$ & $0.6 \pm 0.04$ & 1.75 & 0.12 \\
\hline Uterine artery RI & $\begin{array}{c}0.6 \pm 0.04 \\
\text { ANOVA: analysis of variance }\end{array}$ & & & \\
\hline
\end{tabular}

Table (4): Correlation between uterine artery PI and RI and other parameters using Pearson Correlation Coefficient in all patients

\begin{tabular}{|c|c|c|c|c|c|c|c|}
\hline \multicolumn{2}{|l|}{ Parameters } & $\begin{array}{c}\text { Uterine } \\
\text { artery PI } 0\end{array}$ & $\begin{array}{c}\text { Uterine } \\
\text { artery PI } 3\end{array}$ & $\begin{array}{c}\text { Uterine artery } \\
\text { PI } 6 \text { (group I + } \\
\text { group II/a) }\end{array}$ & $\begin{array}{c}\text { Uterine } \\
\text { artery RI } 0\end{array}$ & $\begin{array}{c}\text { Uterine } \\
\text { artery RI } 3\end{array}$ & $\begin{array}{c}\text { Uterine artery } \\
\text { RI } 6 \text { (group I + } \\
\text { group II/a) }\end{array}$ \\
\hline \multirow{2}{*}{ Dysmenorrhea } & $\mathrm{r}$ & 0.54 & 0.54 & 0.54 & 0.50 & 0.51 & 0.51 \\
\hline & $\mathrm{p}$ & $0.001 *$ & $0.001 *$ & $0.001 *$ & $0.001 * *$ & $0.001 *$ & $0.001 *$ \\
\hline \multirow{2}{*}{$\begin{array}{l}\text { Menstrual } \\
\text { duration }\end{array}$} & $\mathrm{r}$ & -0.12 & -0.54 & -0.54 & -0.12 & -0.50 & -0.50 \\
\hline & $\mathrm{p}$ & 0.07 & $0.001 *$ & $0.001 *$ & 0.07 & $0.001 *$ & $0.001 *$ \\
\hline \multirow{2}{*}{$\begin{array}{l}\text { Amount of bleeding } \\
\text { (pads/cycle) }\end{array}$} & $\mathrm{r}$ & -0.14 & -0.55 & -0.50 & -0.13 & -0.54 & -0.49 \\
\hline & $\mathrm{p}$ & 0.06 & $0.001 *$ & $0.001 *$ & 0.07 & $0.001 *$ & $0.001 *$ \\
\hline \multirow{2}{*}{$\begin{array}{l}\text { Bleeding free } \\
\text { interval }\end{array}$} & $\mathrm{r}$ & 0.07 & 0.28 & 0.29 & 0.07 & 0.26 & 0.26 \\
\hline & $\mathrm{p}$ & 0.25 & $0.001 *$ & $0.001 *$ & 0.37 & $0.001 *$ & $0.001 *$ \\
\hline \multirow{2}{*}{$\mathrm{Hb}(\mathrm{gm} / \mathrm{dl})$} & $\mathrm{r}$ & 0.10 & 0.38 & 0.39 & 0.04 & 0.32 & 0.33 \\
\hline & $\mathrm{p}$ & 0.11 & $0.001 *$ & 0.001 & 0.47 & $0.001 *$ & $0.001 *$ \\
\hline
\end{tabular}

r: Pearson Correlation coefficient, *: p-value $<0.05$.

Table (5): Uterine artery PI and RI cut-off values:

\begin{tabular}{|l|c|c|c|c|c|c|}
\hline $\begin{array}{c}\text { Uterine artery } \\
\text { Doppler indices }\end{array}$ & Cut-off & Sen. & Spe. & PPV & NPV & AUC \\
\hline PI & $\leq 1.52$ & $98.6 \%$ & $96.9 \%$ & $97.8 \%$ & $97.9 \%$ & 98.9 \\
\hline RI & $\leq 0.66$ & $97.8 \%$ & $96.7 \%$ & $97.8 \%$ & $96.9 \%$ & 95.9 \\
\hline
\end{tabular}

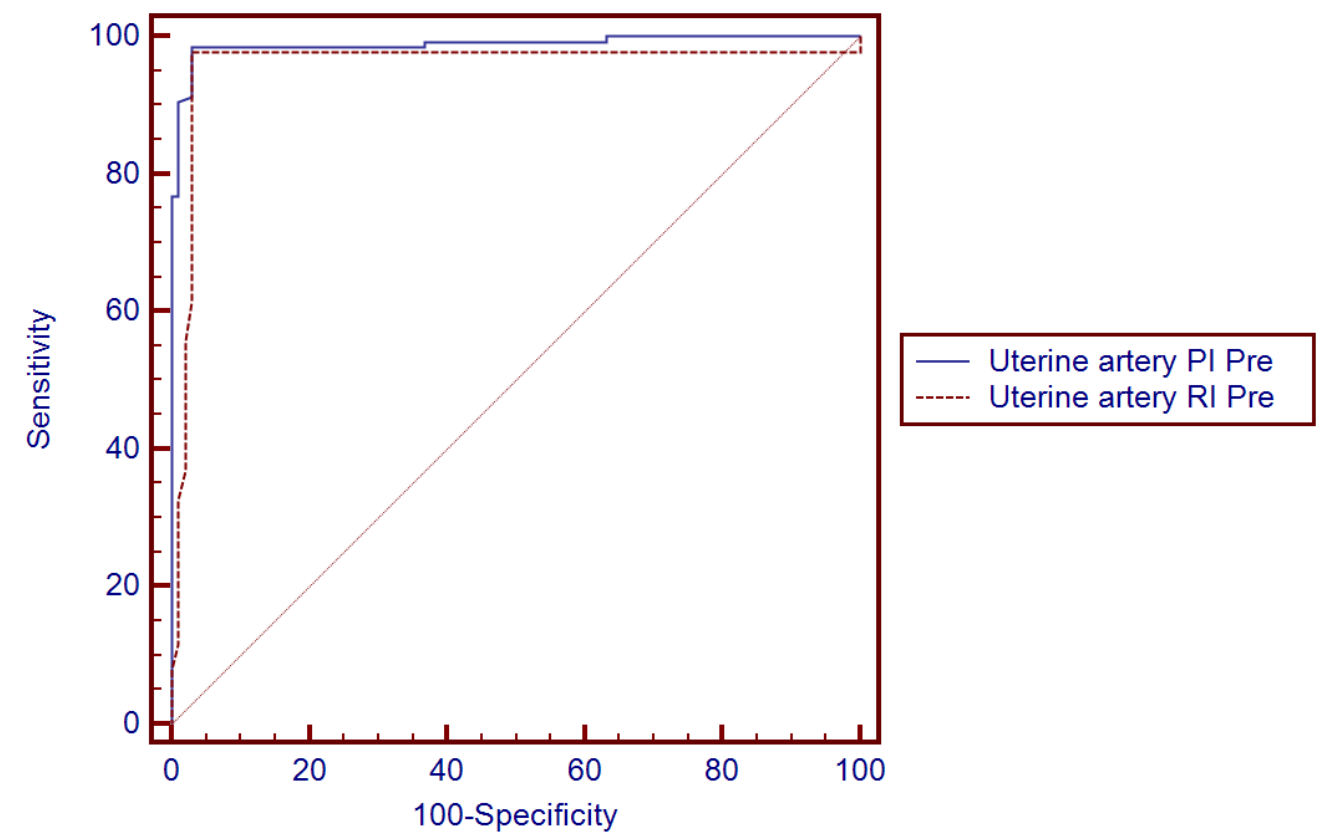

Fig. (3): Receiver-operating characteristic (ROC) curve for prediction of heavy bleeding using uterine artery PI and RI with AUC 98.9 for PI and 95.9 for RI 


\section{DISCUSSION}

Most likely the IUCD adverse effects are somehow related to uterine vascularization, this relation needs more evaluation. Several studies were done to evaluate the role of Doppler Ultrasound of uterine artery in assessment of abnormal uterine bleeding in women using copper IUCD with contradicting results, this controversy urged us to investigate more in this matter [5]

The results of this study showed that there was no statistically significant difference between females in the two groups as regards age, parity, and BMI. These results agree with the results of Mansour et al. [4] Azkoul et al. ${ }^{[5]}$ and Rezk et al. ${ }^{[6]}$.

The results of this study showed a statistically significant increase in the menstrual duration after IUCD insertion in group II (in both subgroups) when compared to group I with no statistically significant change in the cycle length between group I and group II (in both subgroups) before and after IUCD insertion. These results are in accordance with Järvelä et al. ${ }^{[11]}$ and El-Mazny et al. ${ }^{[7]}$ who found a statistically significant increase in the menstrual duration in the heavy bleeding group. But according to Mutlu et al. ${ }^{[12]}$ neither the cycle length nor the menstrual duration showed a statistically significant difference between the groups, in this study they didn't use a menstrual calendar to evaluate the menstrual bleeding, they were only depending on the number of pads used during menstruation.

The results of this study showed a statistically significant increase in the amount of bleeding after IUCD insertion in group II (in both subgroups) when compared to group I. This result agrees with the results of Järvelä et al. ${ }^{[11]}$ El-Mazny et al. ${ }^{7]}$ Mutlu et al. ${ }^{[12]}$ Azkoul et al. ${ }^{[5]}$ and Rezk et al. ${ }^{[6]}$ who found an increase in the amount of bleeding in the heavy bleeding group which was statistically significant difference.

This study showed that nearly half $(52.9 \%)$ of females in group I had primary dysmenorrhea, however all cases in group II have no dysmenorrhea before insertion of IUCD with statistically significant difference. This means that the patient that have history of dysmenorrhea before IUCD is not likely to experience heavy bleeding after insertion. This can be explained by knowing the theories that sharing in the occurrence of primary dysmenorrhea which include increased secretion of endothelin, leukotrienes and platelet activating factors, these factors cause vasoconstriction of uterine arteries with a decrease in the endometrial and myometrial blood flow causing hypoxia and thus decreasing the amount of menstrual bleeding ${ }^{[13]}$.

Our results showed that there was no difference between the two groups in the initial $\mathrm{Hb}$ levels while, statistically significant decrease in $\mathrm{Hb}$ levels after IUCD insertion in group II (in both subgroups) versus group I. In accordance, Rezk et al. ${ }^{[6]}$ found that there was no significant difference in the baseline hemoglobin levels between the two groups with a significant decrease in the hemoglobin levels 3 and 6 months after IUCD insertion in the heavy bleeding group.

This study showed that PI and RI of uterine artery were lower significantly in group II (in both subgroups) than group I either before or after insertion of IUCD with no statistically significant changes in the PI and RI before and after insertion of the IUCD in each individual group, meaning that the IUCD does not affect uterine artery Doppler indices. In agreement, Frajndlich et al. ${ }^{[14]}$ and Rezk et al. ${ }^{[6]}$ found that Doppler indices of uterine artery were lower in the heavy bleeding group than the normal bleeding group. However, Frajndlich et al. ${ }^{[14]}$ found that PI and RI of uterine artery were lower in the group of women using IUCD and suffering menorrhagia (either taking medications or not) than those without menorrhagia. These results of Frajndlich et al. ${ }^{[14]}$ cannot be used for prediction of IUCD-induced menorrhagia as they lack information about uterine artery Doppler indices before IUCD insertion. They also enrolled patients using medications that may alter uterine vascularization. Also, Rezk et al. ${ }^{[6]}$ reported that among 332 women who inserted IUCD, the heavy bleeding group (n: 144) showed lower Doppler indices of uterine artery when compared to the normal bleeding group (n: 188) before and after IUCD insertion. In accordance with our previous results, Järvelä et al. ${ }^{11}$, De Souza and Geber ${ }^{15]}$, Mutlu et al. ${ }^{[12]}$ and Rezk et al. ${ }^{[6]}$ concluded that there were no statistically significant changes in uterine artery blood flow among women who experienced heavy bleeding after IUCD insertion. In contrast to our study, Momtaz et al. ${ }^{[16]}$ Fouda et al. ${ }^{[17]}$ and Mansour et al. ${ }^{[4]}$ concluded that IUCD insertion causes changes in uterine artery Doppler indices as they found that uterine artery vascular impedances were significantly lower in women with IUCD induced heavy menstrual bleeding than in those using IUCD with no heavy menstrual bleeding and there were no statistical significant differences in PI and RI of uterine artery between women using IUCD with no heavy menstrual bleeding and women not using any contraceptive method. The main drawback in the previous 3 studies is that they didn't measure PI and RI of uterine artery before IUCD insertion, this may explain the conflicting results between these studies and our study.

A study done by Azkoul et al. ${ }^{[5]}$ concluded that there was no statistically significant difference in PI and RI of uterine artery between women with IUCD-induced menorrhagia and women with no IUCD-induced menorrhagia, meaning that neither the presence of IUCD nor the associated abnormal bleeding seem to be related to any alteration in the uterine artery blood flow. These results are in contrast with our results, this could be explained by several factors; they did not measure uterine artery PI and RI before IUCD insertion, also they recruited a small number of patients. 
In Jiménez et al. ${ }^{[8]}$ El-Mazny et al. ${ }^{[7]}$ Mansour et al. ${ }^{[4]}$ and Anwar et al. ${ }^{[18]}$ they evaluated the effect of IUCD on the sub-endometrial blood flow and they all reported a statistically significant increase after IUCD insertion in the patients who reported menorrhagia.

In our study there was a highly statistically significant negative correlation between uterine artery Doppler indices and menstrual duration and amount of bleeding 3 and 6 months after IUCD insertion. There was also a highly statistically significant positive correlation between uterine artery Doppler indices and dysmenorrhea, bleeding free interval and $\mathrm{Hb}$ concentration, before insertion and 3 and 6 months after insertion in case of dysmenorrhea and 3 and 6 months after insertion in case of bleeding free interval and $\mathrm{Hb}$ concentration. This is in contradictory to Jiménez et al. ${ }^{[8]}$ and Mutlu et al. ${ }^{[12]}$ who reported no statistically significant correlation between uterine artery PI and RI and dysmenorrhea or the amount of bleeding.

In our study, cut-off levels for uterine artery PI and RI were set with PI level $\leq 1.52$ and RI level $\leq 0.66$, these values are associated with heavy menstrual bleeding. Several studies have found different sets of cut-off levels for prediction of IUCD related menorrhagia, and this needs meta-analysis of such studies or further large studies to put a standard cut-off value.

\section{CONCLUSION}

From this study we can conclude that the uterine artery Doppler indices are lower in women who experienced IUCD-related heavy menstrual bleeding than those with no IUCD-induced heavy menstrual bleeding before IUCD insertion. IUCD does not affect uterine artery color Doppler indices after insertion. Cut off values of uterine artery $\mathrm{PI} \leq 1.52$ and $\mathrm{RI} \leq 0.66$ are associated with heavy menstrual bleeding after IUCD insertion. Initial measurement of uterine artery Doppler indices (PI and RI) before IUCD insertion could be useful in predicting IUCD-induced heavy menstrual bleeding which is the major cause of method withdrawal during the first year of use and accordingly women should be counselled to consider another method of contraception.

Conflict of interest: No direct or indirect conflict of interest

Financial support: This work not funded from any governmental or non-governmental agencies.

\section{REFERENCES}

1. Forthofer KV. A Clinical Review of the Intrauterine Device as an Effective Method of Contraception. JOGNN - Journal of Obstetric, Gynecologic and Neonatal Nursing, 2009; 38(6): 693-698.

2. Sivin I and Batár I. State-of-the-Art of NonHormonal Methods of Contraception: III. Intrauterine Devices. European Journal of Contraception and Reproductive Health Care, 2010; 15(2): 96-112.
3. Marret H, Fauconnier A, Chabbert-Buffet N, Cravello L, Golfier F, Gondry J, et al. Clinical Practice Guidelines on Menorrhagia: Management of Abnormal Uterine Bleeding before Menopause. European Journal of Obstetrics and Gynecology and Reproductive Biology, 2010; 152(2): 133-137.

4. Mansour GM, Hussein SH, Mohammed HF, El Mekkawy SF, Akl SA and Abd El Dayem AA. Can We Predict Menorrhagia with Intrauterine Contraceptive Device (IUCD) Insertion? Open Journal of Obstetrics and Gynecology, 2017; 7(7): 753-766.

5. Azkoul Z, Abdel-Azeem S, Nassif A and Sharaf A. Role of Uterine Artery Doppler in Assessment of Abnormal Uterine Bleeding in Females Using Copper Contraceptive Intrauterine Device. Medical journal of Cairo University, 2017; 85(8): 3029-3036.

6. Rezk M, Elkelani O, Gaber W and Shawky M. Pre-insertion uterine artery Doppler indices may predict intrauterine contraceptive device-related heavy menstrual bleeding, Middle East Fertility Society Journal, 2018; 23(4): 496-500.

7. El-Mazny A, Abou-salem $\mathbf{N}$ and Elshenoufy $\mathbf{H}$. Three-dimensional power Doppler study of endometrial and subendometrial microvascularization in women with intrauterine device-induced menorrhagia. Fertility and Sterility, 2013; 99(7): 1912-1915.

8. Jiménez MF, Vetori D, Fagundes PP, De Freitas FM and Cunha-Filho JL. Subendometrial Microvascularization and Uterine Artery Blood Flow in IUD-Induced Side Effects (Levonorgestrel Intrauterine System and Copper Intrauterine Device). Contraception, 2008; 78(4): 324-327.

9. World Health Organization Task Force on Psychosocial Research in Family Planning, Special Programme of Research, Development and Research Training in Human Reproduction. Women's Bleeding Patterns: Ability to Recall and Predict Menstrual Events. Studies in Family Planning, 1981; 12(1): 17-27.

10. Bluestone J. Follow-up care and management of potential problems. In R. Chase and E. R. Lu (Eds), IUD guidelines for family planning service programs.2006: pp. 6-1 - 6-5. Baltimore, MD: JHPIEGO.

11. Järvelä I, Tekay A and Jouppila $\mathbf{P}$. The effects of a copper-intrauterine device on the uterine artery blood flow in regularly menstruating women. Human reproduction (Oxford, England), 1998; 13(7): 1841-1845.

12. Mutlu I, Demir A and Mutlu MF. Can uterine artery Doppler parameters predict copper intrauterine device-induced side effects? The European journal of contraception and reproductive health care, 2014; 19(1): 51-56.

13. Dutta DC. Contraception. In H. Konar (Eds.), DC DUTTA's Textbook of Gynecology 2014: pp. 475-504. New Delhi, I: Jaypee Brothers Medical Publishers, (P) Ltd.

14. Frajndlich $R$, von Eye Corleta $H$ and Frantz $\mathbf{N}$. Color Doppler sonographic study of the uterine 
artery in patients using intrauterine contraceptive devices. Journal of ultrasound in medicine, 2000; 19(8): 577-579.

15. De Souza MA and Geber S. Doppler color flow analysis of the uterine arteries before and after intrauterine device insertion: a prospective study. Journal of ultrasound in medicine, 2006; 25(2): 153-157.

16. Momtaz M, Zayed M, Rashid $K$ and Idriss $O$. Doppler study of the uterine artery in patients using an intrauterine contraceptive device. Ultrasound in obstetrics and gynecology, 1994; 4(3): 231-234.
17. Fouda, UM, Yossef D and Gaafar HM. Uterine artery blood flow in patients with copper intrauterine device-induced abnormal uterine bleeding. Middle East Fertility Society Journal; 2010; 15(3): 168-173.

18. Anwar MHH, Abu Shady Y, Abdel-Aziz BR and Ashour AEE. Doppler Characteristics of Sub-endometrium and Uterine Hemodynamic Changes in Patients with Copper Intrauterine Device-induced Bleeding. The Egyptian Journal of Hospital Medicine, 2019; 75(1): 2020-2025. 


\section{الملخص العزبي}

\section{هل تستطيع مؤشرات الاوبلر علي الثريان الرحمي قبل تركيب اللولب التنبؤ بحدوث نزيف بوديف

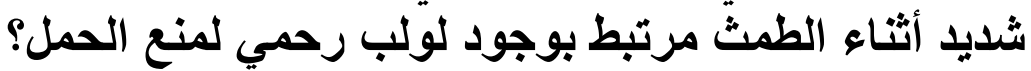

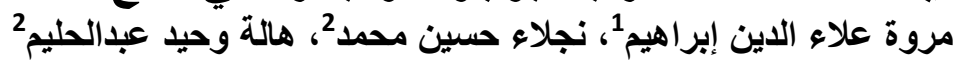

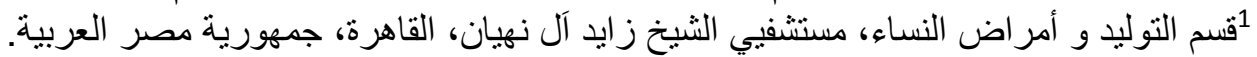 \\ 2قسم التوليد و أمر اض النساء، كلية طب البنات، القاهرة، جامعة الأزهر، جمهورية مصرة النهر العربية.}

\section{ملخص البحث}

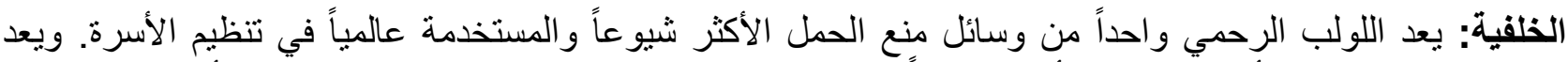

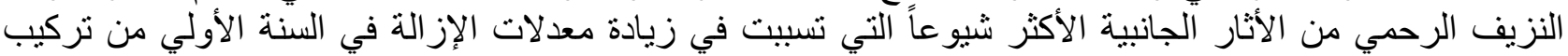
اللولب.

الهُف: اختبار افتر اضية أن الدوبلر الأولي علي الثريان الرحمي لمؤشر النبض ومؤشر المقاومة قبل نركيب اللولب

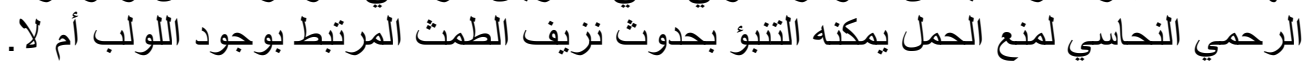

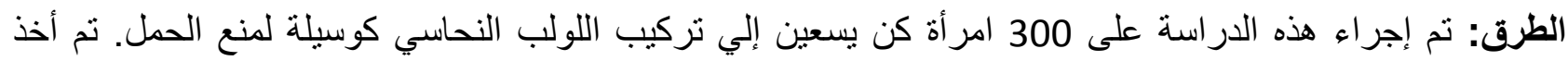

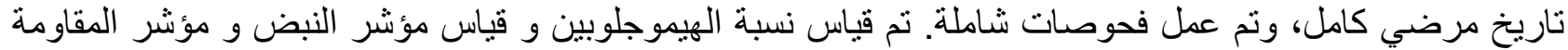

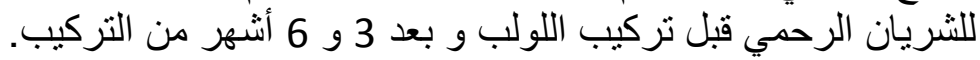

النتائج: 162 مشاركة عانين من نزيف طمث غزير ( المجموعة الثانية) كان لديهن انخفاض ملحوظ في مؤشرات النبض و المقاومة للثريان الرحمي مقارنة ب 138 مشاركة لم يعانين من نزيف طمث غزير (المجموعة الأولي) قبل

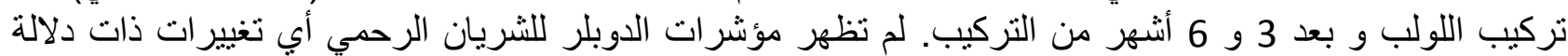

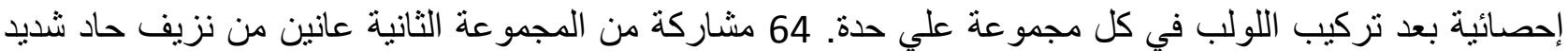

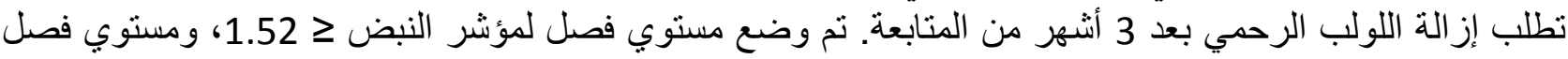
لمؤشر المقاومة $20,66$.

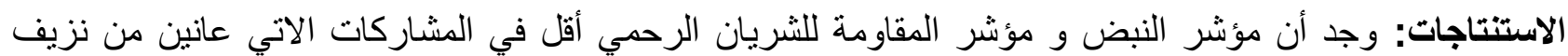

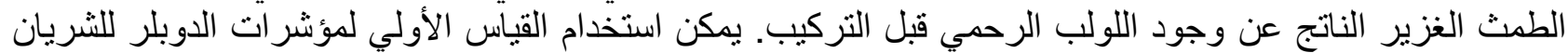
الرحمي قبل تركيب اللولب في التنبؤ بحدوث نزيف الطمث الغزير الناتج عن اللولب الرئ الرحمي.

الكلمات المفتاحية: اللولب الرحمي النحاسي، نزيف الطمث الغزير، مؤشرات الدوبلر للشريان الرحمي.

الأسباحث: مروة علّاء الدين إبر اهيم، قسم التوليد و أمر اض النساء، مستشفيب الثيخ زايد آل نهيان، القاهرة، جمهورية مصر

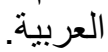
الهراتف: الإكربة: 01030353009 البريد الإكتروني: marwa.unique@gmail.com 